\title{
松下電器産業侏) 電化研究所
}

\section{近藤 信ニ*}

電化研究所は、昭和 37 年に松下電器産業(怢電化 本部のグループ研究所として発足しました。電化 研究所の役割は電化本部の技術発信基地として、 電化本部傘下の 5 つの事業部 (洗濯機、掃除機、ア イロン、電化調理、炊飯機器)の事業分野に関する 中長期的な先行技術や新規商品の研究開発を行う ことです。組織としては 6 つの研究室から成る研 究部と研究助成部とで構成されています。ファジ 亿技術の電化商品への応用は研究室の一つである 電子技術第 1 研究室内の知能化グループで行って おり、筆者もそのグループに属しています。知能 化グループではファジィ、ニューロといった知的 情報処理技術を核として電化商品の知的制御、七 ユーマンインターフェイス、知能化センサ等の研 究開発を行っています。

電化研究所がファジイ技術を導入したのは 1988 年で、1989 年 4 月の松下技術総合展に出展し た掃除ロボットの走行制御に応用したことに始ま ります。当初掃除ロボットの走行制御に従来の線 形制御を用いていましたが、進路变更時に目標ラ インへの収束性が良くないという課題がありまし た。そこで当時注目を集めだしていた(松下電器と しては中央研究所で先行研究していた)ファジィ 技術を適用してみたところ良好な結果が得られた とともに、ファジィ技術の使い勝手の良さが実証 されました。特に電化商品で扱う对象は洗濯物の 污れ具合やお米の状態といった曖昧なファクター が多く、制御対象の数学モデルの構築が困難であ るため、厳密な数学モデルを必要としないファジ イ制御は電化商品の制御手段として有益であると 考えられました。

1990 年 2 月に最初のファジィ家電である全自 動洗濯機を発売以降、掃除機、炊飯器と主力商品

\footnotetext{
* Shinji KONDOH

松下電器産業株式会社 電化研究所

Matsushita Electric Industrial Co., Ltd.
}

へのファジィ応用を展開し、更に商品のインテリ ジェンス化を図るためニューロ・ファジィ技術を 導入しました。この間家電業界はファジィ家電ブ 一ムが起こり家電商品がファジィ一色に染まりま した。なぜこのようにファジィ家電ブームが起こ ったのかというと、「ファジィ」という言葉の持つ イメージ、フィーリングが大衆受けしたというこ ともありますが、基本的にはファジィ家電が機 能・性能面で従来よりも向上し、より使い勝手の 良い商品であったからだと考えられます。また短 期間にファジイ家電を次々と開発できた理由とし ては、主力家電商品のほとんどにマイコンが搭載 されているとともに、各種センサやアクチュエー タがすでに開発されていたためファジィ家電の典 型的なファジイ制御を容易に実現できたことや、 炊飯の「はじめチョロチョロ、なかパッパ…」に 代表される、ファジィ制御に必要な各種ノウハウ の蓄積があったこと等が挙げられると思います。

少し余談になりましたが、ここで電化研究所の 概要を紹介したいと思います。研究所員はおおよ そ機構系、電気系、材料系の技術者と生活ソフト 研究のメンバーとで構成されています。研究開発 テーマは事業部からの委託テーマと自ら設定する 自主テーマがあり、前者は近未来商品のための技 術開発、後者は中長期ビジョンに立った要素技術 の研究開発をターゲットとしています。またプロ ジェクトチームを発足して事業部にどっぷり浸か つて量産まで担当することもあります。このよう に基礎研究から量産設計に至るまで幅広い仕事が 混在し、また経験できるところが電化研究所の魅 力の一つです。研究開発環境は「ボチボチでんな 一」といったところですが、基本的に自主性が主 体の自由な風土が特徴です。実験室には洗濯機、 炊飯器、トースター等、様々な電化商品が所狭し と並びEWS やパソコンとつながって動いていま 
す。炊飯実験をしている横では掃除機がうなって いたり、ロッカーには洗濯実験用の衣類がぎっし ク詰まっていたりするのは電化機器の研究所なら ではの光景です。また自分の作業着を実験用洗濯 機でこっそり洗濯したり、実験廃棄物のご飯やト ーストをおやつにしたりといったメリットもあり ます。いずれにしても、適度な「緊張」と「ゆと り」のある職場です。

最後に、ファジィ家電ブームが過ぎ去り「ポス トファジィは‥?」という声をよく耳にしますが、 実際はブームが過ぎただけであってファジィが不 要になったわけでは無く、むしろやっと本物の基 本技術の一つになってきたのだ思います。現在の
電化商品は本質性能・本質機能の時代に入ってい ますが、その要素にファジィ、ニューロといった 知能化技術が今後も活かされて行くと思います。

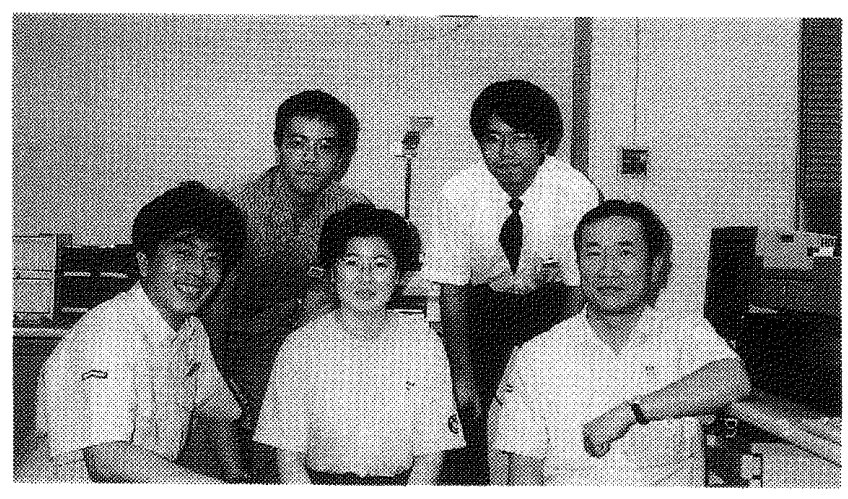

電化研究所 実験室にて 